(c) American Dairy Science Association, 2005.

\title{
Low-Fat Mozzarella as Influenced by Microbial Exopolysaccharides, Preacidification, and Whey Protein Concentrate
}

\author{
B. Zisu and N. P. Shah \\ School of Molecular Sciences, Victoria University, Werribee Campus, PO Box 14428 \\ Melbourne City Mail Center, Victoria 8001, Australia
}

\begin{abstract}
Low-fat Mozzarella cheeses containing 6\% fat were made by preacidification of milk, preacidification combined with exopolysaccharide- (EPS-) producing starter, used independently or as a coculture with nonEPS starter, and preacidification combined with whey protein concentrate (WPC) and EPS. The impact of these treatments on moisture retention, changes in texture profile analysis, cheese melt, stretch, and on pizza bake performance were investigated over $45 \mathrm{~d}$ of storage at $4^{\circ} \mathrm{C}$. Preacidified cheeses without EPS (control) had the lowest moisture content $(53.75 \%)$. These cheeses were hardest and exhibited greatest springiness and chewiness. The meltability and stretchability of these cheeses increased most during the first $28 \mathrm{~d}$ of storage. The moisture content in cheeses increased to 55.08, 54.79 , and $55.82 \%$ with EPS starter (containing 41.18 $\mathrm{mg} / \mathrm{g}$ of EPS), coculturing (containing $28.61 \mathrm{mg} / \mathrm{g}$ of EPS), and WPC (containing $44.23 \mathrm{mg} / \mathrm{g}$ of EPS), respectively. Exopolysaccharide reduced hardness, springiness, and chewiness of low-fat cheeses made with preacidified milk in general and such cheeses exhibited an increase in cohesiveness and meltability. Although stretch distance was similar in all cheeses, those containing EPS were softer than the control. Cocultured cheeses exhibited the greatest meltability. Cheeses containing WPC were softest in general; however, hardness remained unchanged over $45 \mathrm{~d}$. Cheeses made with WPC had the least increase in meltability over time. Incorporation of WPC did not reduce surface scorching or increase shred fusion of cheese shreds during pizza baking; however, there was an improvement in these properties between $\mathrm{d} 7$ and 45 . Coating of the cheese shreds with oil was necessary for adequate browning, melt, and flow characteristics in all cheese types.
\end{abstract}

(Key words: exopolysaccharide, preacidification, coculture, whey protein concentrate)

Received June 4, 2004.

Accepted February 28, 2005.

Corresponding author: Nagendra Shah; e-mail: Nagendra.Shah@ vu.edu.au.
Abbreviation key: EPS = exopolysaccharides, UTM = Instron universal testing machine, WPC $=$ whey protein concentrate.

\section{INTRODUCTION}

Fat in Mozzarella cheeses contributes to stretch and flow by providing a lubricating effect when melted. During pizza baking, there is a substantial release of free oil, which reduces surface scorching. Lowering the fat content compromises the overall texture and functionality. The ratio of moisture to protein is reduced, creating harder cheeses. The reduced fat content does not allow for adequate free oil release and hinders the pizza bake performance. Several reports have shown that low-fat Mozzarella cheeses have less tendency to melt and have inferior baking characteristics to full-fat cheeses (Fife et al., 1996; Rudan and Barbano, 1998b). The cheeses were observed to be tougher, more brittle, and less pliable (Fife et al., 1996) than full-fat cheeses.

Rudan and Barbano (1998b) showed that low-fat Mozzarella cheeses could be baked to exhibit similar melting and browning characteristics to those of the full-fat variety. This was achieved by coating cheese shreds with a hydrophobic material before baking to prevent surface dehydration and subsequent skin formation.

As both fat and unbound water act as a lubricant and increase the ability of cheese particles to flow, the impact of moisture content of low-fat Mozzarella on its functionality has been investigated. Various studies have shown that the moisture content of low-fat Mozzarella cheeses affects their functionality (Fife et al., 1996; McMahon et al., 1996; Perry et al., 1997, 1998; Low et al., 1998; McMahon and Oberg, 1998; Petersen et al., 2000). By increasing the ratio of moisture to protein equal to or greater than that observed in full-fat Mozzarella cheeses, low-fat cheeses were made softer and the melt and functionality were improved.

Strains of exopolysaccharide- (EPS-) producing lactic acid bacteria have been used successfully to manufacture low-fat Mozzarella cheeses with improved moisture retention and functional properties (Perry et al., 1997; Petersen et al., 2000). Textural properties have 
also been altered in rennet-set curds and fermented milks made with EPS-producing cultures (Hassan et al., 1996a,b; Hassan and Frank, 1997; Rawson and Marshall, 1997; Marshall and Rawson, 1999; Hassan et al., 2002). Microbial EPS are extracellular, bind water, and retard whey expulsion (De Vuyst and Degeest, 1999). Microorganisms that produce capsular EPS, which remain attached to the cell surface to create a discrete covering, are of particular importance as they show negligible adverse affects on processing of whey (Perry et al., 1997; Low et al., 1998; Petersen et al., 2000).

In our earlier study (Zisu and Shah, 2003), we found that coculturing an EPS-producing Streptococcus thermophilus strain with a nonEPS Strep. thermophilus greatly increased EPS production. The increase in EPS synthesis was due to the complementary relationship between the 2 strains of Strep. thermophilus to produce a constant supply of essential nutrients.

We also reported that EPS production increased when the medium was supplemented with whey protein concentrate (WPC) (Zisu and Shah, 2003). In addition to its influence on cell growth and EPS synthesis, incorporation of WPC may influence changes in texture and functionality of Mozzarella cheese. Such changes, however, may depend on the solubility of commercially available WPC that is known to be highly variable.

Calcium plays an important role on the texture of Mozzarella cheese by cross-linking proteins (Metzger et al., 2000b). The calcium content is known to be greater in low-fat cheeses, contributing to the hardness of the product. Removing some calcium from casein micelles by preacidification of the cheese milk with an acid before enzymic coagulation allows for the manufacture of a softer cheese with greater flow when melted because of reduced cross-linking between casein polymers. Our recent findings (Zisu and Shah, accepted), supported by others (Feeney et al., 2002; Joshi et al., 2003) suggest that preacidification also increases the rate of primary proteolysis by the action of residual coagulant in low-fat Mozzarella cheeses. As a combined result of proteolysis and degradation of the milk protein matrix, the meltability of Mozzarella cheese has been shown to improve (Fife et al., 1996; Zisu and Shah, accepted).

The effects of combining the technique of preacidification, the use of EPS starter cultures and incorporation of WPC in low fat Mozzarella cheese are not known. Similarly, little is known about EPS synthesis in cheeses, in general, as influenced by coculturing and use of WPC. The aims of this study were to investigate the effects of combining preacidification and use of EPS starter, alone and as a coculture with a nonEPS producer, and WPC on moisture retention, EPS production, texture, meltability, stretchability, and pizza baking of low-fat Mozzarella cheeses containing 6\% fat.

\section{MATERIALS AND METHODS}

\section{Starter Cultures}

Streptococcus thermophilus strains 285 and 1303 and Lactobacillus delbrueckii ssp. bulgaricus strain 1368 were obtained from the Australian Starter Culture Research Center (ASCRC, Werribee, Victoria, Australia). Streptococcus thermophilus 285 was previously identified as a capsular EPS-producing strain (Zisu and Shah, 2002). Microorganisms were stored at $-80^{\circ} \mathrm{C}$ in $10 \%$ (wt/vol) reconstituted skim milk containing 20\% (vol/ vol) glycerol. Working cultures were propagated 3 times consecutively using $1 \%$ (vol/vol) inoculum in $10 \%$ reconstituted skim milk at $37^{\circ} \mathrm{C}$ for $18 \mathrm{~h}$ before use.

\section{Cheese Making}

Each batch of cheese was made with $25 \mathrm{~L}$ of whole, raw milk obtained from Mamma Lucia Cheese (Fresh Cheese Co. Pty. Ltd., Brunswick, Victoria, Australia). The cream was separated using a batch 107 AE-type cream separator (Alfa Laval; APV Australia, Clayton, Victoria, Australia). Skim milk (0.005\% fat) and whole milk ( $3.4 \%$ fat) were pasteurized at $72^{\circ} \mathrm{C}$ for $15 \mathrm{~s}$ using an Alfa Laval P20 HRB pasteurizer (Alfa Laval). The pasteurized skim milk and whole milk were standardized to $0.5 \%$ fat, which was used to make 4 batches of cheese with a final fat content of $6 \%$ as indicated below.

Batch 1. Preacidification + Strep. thermophilus 1303 (nonEPS) $+L$. delbrueckii ssp. bulgaricus 1368 (nonEPS) (Control)

Batch 2. Preacidification + Strep. thermophilus 285 (EPS) + L. delbrueckii ssp. bulgaricus 1368 (nonEPS)

Batch 3. Preacidification + Strep. thermophilus 285 (EPS) $(75 \%)+$ Strep. thermophilus 1303 (nonEPS) $(25 \%)+$ L. delbrueckii ssp. bulgaricus 1368 (nonEPS)

Batch 4. Preacidification + Strep. thermophilus 285 (EPS) + L. delbrueckii ssp. bulgaricus 1368 (nonEPS) + WPC $392(0.125 \% \mathrm{wt} / \mathrm{vol})(80.4 \%$ protein; New Zealand Milk Products (Australia) Pty. Ltd., Rowville, Victoria, Australia).

Starter bacteria were inoculated at a concentration of $1.6 \%$ of Strep. thermophilus and $0.8 \%$ of $L$. delbrueckii ssp. bulgaricus. Cheese milk of batch 3 was inoculated with a coculture of EPS producing Strep. thermophilus $285(0.75 \%)$ and nonEPS Strep. thermophilus 1303 
(0.25\%). WPC 392 was added to milk at $0.125 \%$ (wt/wt) for batch 4 .

Cheese milk was tempered to $35^{\circ} \mathrm{C}$ for $30 \mathrm{~min}$ and preacidified to $\mathrm{pH} 6.1 \mathrm{using} 50 \%$ (wt/vol) citric acid. A $100-\mathrm{mL}$ aliquot of milk was collected and stored at $-20^{\circ} \mathrm{C}$ for analysis. Single strength chymosin (Chymax; Chr. Hansen, Pty. Ltd., Bayswater, Victoria, Australia) was added at the rate of $12.5 \mathrm{~mL}$ per $25 \mathrm{~L}$ of milk. A setting time of 15 min was applied while maintaining a temperature of $35^{\circ} \mathrm{C}$. The set curd was cut using a cheese knife of $1-\mathrm{cm}$ grid based on the setting time. The subjective assessment of the coagulum was also carried out. After cutting, curds were cooked for $20 \mathrm{~min}$, gradually increasing the temperature to $40^{\circ} \mathrm{C}$. Whey was drained at $\mathrm{pH} 6.1$ and stored at $-20^{\circ} \mathrm{C}$ for analysis. The curd was cheddared into slabs before milling at pH 5.2. Salt was added to the curd at 1.5\% (wt/wt) and held for $30 \mathrm{~min}$. Curd ( $40 \mathrm{~g}$ ) was collected for later analysis and stored at $-20^{\circ} \mathrm{C}$. The remaining curd was then stretched for $7 \mathrm{~min}$ in hot water $\left(75^{\circ} \mathrm{C}\right)$ containing $3 \%$ salt (wt/ wt) at a volume 2.5 times the weight of the curd. Stretch water was frozen at $-20^{\circ} \mathrm{C}$ for later analysis.

An appropriate sample size from each cheese was removed for analysis and frozen at $-20^{\circ} \mathrm{C}$. Cheeses were immediately placed into barrier bags and vacuum sealed using a Multivac A300/16 machine (Multivac Sepp Haggenmuller KG, Wolfertschwenden, Germany) followed by storing at $4^{\circ} \mathrm{C}$. All cheeses had a pH of 5.2 at the end of manufacture. Although different strains of Strep. thermophilus were used, the growth rate between the selected strains of EPS and nonEPS starter cultures is known to be similar. Hence, no major difference in acidification rate was expected during storage.

\section{Cheese Analysis}

Each cheese was analyzed for fat (Babcock method), moisture (atmospheric oven method on the day following production), and protein (Kjeldahl method) contents in accordance with AOAC methods (AOAC, 1999). Textural characteristics, stretch, and meltability of each cheese were performed at $d 7,14,28$, and 45 . A pizza bake test was carried out at d 28 and 45 .

\section{Isolation and Quantification of Exopolysaccharides}

Frozen 100-mL aliquots of milk, whey, and stretching water from each batch of cheese were thawed overnight at $4^{\circ} \mathrm{C}$. For preparation of cheese and curd, a $100-\mathrm{mL}$ volume of distilled water was mixed with $15 \mathrm{~g}$ of finely chopped sample and homogenized at 25,000 rpm for 2 min using a Ultra Turrax homogenizer (T25, Janke \& Kunkel GmbH \& CoKG, Staufen, Germany). Exopolysaccharide was extracted by ethanol precipitation and quantified by the phenol-sulfuric acid method in each sample according to the procedure described by Zisu and Shah (2003).

\section{Determination of Calcium}

An atomic absorption spectrophotometer (Spectra AA400, Varian Australia Pty. Ltd., Mulgrave, Victoria, Australia) with an air $(13.5 \mathrm{~L} / \mathrm{min}) /$ acetylene $(2.0 \mathrm{~L} /$ min) flame was used to determine the calcium content in cheese, curd, milk, whey, and stretch water as described by Metzger et al. (2000a). Sample sizes and dilution volumes were slightly modified to allow for variations in mineral content. A calcium atomic spectroscopy standard (containing $993 \mu \mathrm{g} / \mathrm{mL}$ of calcium in $1 \% \mathrm{HCl}$; Sigma-Aldrich Co., St. Louis, MO) was used to prepare working standards made up in a mixture of $49.2 \%$ distilled water, $48.7 \%$ of $12 \%$ (wt/vol) TCA, and $2.1 \%$ of $5 \%(\mathrm{wt} / \mathrm{vol})$ lanthanum oxide.

\section{Cheese Meltability}

Meltability of Mozzarella cheeses was determined in 250-mm long glass tubes with a diameter of $24 \mathrm{~mm}$ and a thickness of $3 \mathrm{~mm}$ (R.B. Instruments, Mt. Eliza, Victoria, Australia). The method adopted was similar to that described by Poduval and Mistry (1999). A plunger was used to pack $10 \mathrm{~g}$ of finely grated cheese into the glass tubes that were sealed at one end with a rubber stopper. The other end was sealed with a perforated rubber stopper to enclose the sample. The length of the compressed cheese sample was measured using a Vernier caliper and stored at $4^{\circ} \mathrm{C}$ for $4 \mathrm{~h}$ to allow an even temperature distribution within the sample. Tubes were placed horizontally into an oven preheated to $110^{\circ} \mathrm{C}$ and melted for $100 \mathrm{~min}$. Cheeses were allowed to cool to room temperature $\left(\sim 22^{\circ} \mathrm{C}\right)$ and the length of the melted cheese was recorded. The difference in the initial and the final length was presented as the melt distance.

\section{Texture Profile Analysis}

To determine cheese characteristics including hardness, cohesiveness, springiness, and chewiness, texture profile analysis was performed with an Instron Universal Testing Machine (UTM) (model 5564; Instron Ltd., London, UK) at room temperature $\left(\sim 22^{\circ} \mathrm{C}\right)$ based on a 2 -cycle compression. The details of the texture parameters have been described elsewhere (Pons and Fiszman, 1996). Cheese samples were taken using a $20-\mathrm{mm}$ diameter cylindrical corer and cut to a length of $20 \mathrm{~mm}$ using a specially designed cutting device. Each sample was allowed to equilibrate to room temperature for $10 \mathrm{~min}$ 
after removing from refrigerated storage $\left(4^{\circ} \mathrm{C}\right)$. A 500$\mathrm{N}$ load cell was used with a flat plunger, and samples were compressed to $50 \%$ of their original height at a speed of $50 \mathrm{~mm} / \mathrm{min}$ to allow adequate deformation to occur without breaking the samples. Data were collected using Merlin software according to Bhaskaracharya and Shah (1999).

\section{Cheese Stretchability}

Cheese stretch was performed using the UTM fitted with a 100-N load cell according to the method described by Bhaskaracharya and Shah (2002). The stretch limit was, however, increased to $450 \mathrm{~mm} / \mathrm{min}$. Briefly, a cross bar spindle was placed at the bottom of a beaker and covered with $50 \mathrm{~g}$ of shredded cheese sample that was packed tightly around the spindle with a rubber head plunger. The beaker was covered with aluminum foil to avoid evaporation of the sample and heated in a water bath at $62^{\circ} \mathrm{C}$ for $1 \mathrm{~h}$ to uniformly melt the cheese. The cross bar spindle was attached to the UTM immediately upon removal from the water bath and stretched at $450 \mathrm{~mm} / \mathrm{min}$. The cheese stretch distance, recorded as the distance the cheese was pulled vertically before the sample broke, and resistance [force $(\mathrm{N})]$ were recorded simultaneously using Merlin software.

\section{Pizza Bake}

Shredded Mozzarella cheese (300 g) was used as a topping on a pizza base (Don Emilio's, Freshwell Foods, Coolaroo, Victoria, Australia) covered with a thin layer of tomato paste (Leggos, Simplot Australia Pty. Ltd., Cheltenham, Victoria, Australia). One-half of each pizza was topped with untreated cheese shreds (150 g) and the other half was covered with cheese shreds coated with $1 \%$ (wt/wt) canola oil (Woolworths Home Brand, Yennora, NSW, Australia). On d 28 and 45, pizzas were baked at $262^{\circ} \mathrm{C}$ for $7 \mathrm{~min}$ using a Lincoln Impinger 1304-4 conventional pizza oven (Lincoln Foodservice Products Inc., Fort Wayne, IN) to imitate the conditions used by pizza restaurants (Rudan and Barbano, 1998b). The appearance of the cheese on the pizza was then evaluated for shred fusion and melt, color, and extent of blistering. The Hunter $L^{*} a^{*} b^{*}$ system was used to measure L-values (whiteness) of cheese before cooking, after baking, and after cooling (30 min after baking) with a Minolta Chroma-meter (CR-300, Minolta Corporation, Ramsey, NJ).

\section{Statistical Analyses}

Each batch of cheese was made in triplicate and results are presented as a mean $\pm \mathrm{SE}$ of replicates. Mois- ture, protein, hardness, cohesiveness, springiness, and chewiness results are an average of 9 analyses, and the results of fat, EPS, meltability, and stretchability are representative of 6 analyses. Calcium analysis was recorded as a mean of 6 to 12 replicates. Pizza bakes were replicated 3 times. Hunter L-values obtained from the pizza bake are representative of 9 readings. To find significant differences between analyses, the means were analyzed using 1-way ANOVA with a 95\% confidence interval using Microsoft Excel StatPro (Palaside Corporation, Newfield, NY). The ANOVA data with $P$ $<0.05$ were considered statistically significant.

\section{RESULTS AND DISCUSSION}

All cheeses were made from milk preacidified with citric acid to maintain the uniformity of calcium levels. Any variation between cheeses would therefore be attributed to the effects of EPS and WPC. Our previous findings (B. Zisu and N. P. Shah, unpublished data, 2005) have shown that preacidification of the cheese milk reduced hardness and increased meltability of cheeses over those that were made without preacidified milk and showed some reduction in surface scorching during pizza. Preacidification did not, however, improve moisture retention. The relationship between acid treatment and its influence on calcium content, proteolysis, and functionality of low-fat Mozzarella cheeses has been demonstrated by other researchers (Paulson et al., 1998; Guinee et al., 2002; Joshi et al., 2003; Rehman et al., 2003).

\section{Yield and Composition}

The role of incorporating WPC as well as using the coculture combination of $75 \%$ of EPS producing Strep. thermophilus and 25\% of nonEPS Strep. thermophilus on EPS synthesis was described in our earlier work (Zisu and Shah, 2003). It was found that EPS production was substantially increased in controlled fermentation by the use of WPC as well as by coculturing with EPS-producing Strep. thermophilus strains. In the present study, we examined the effects of these in cheese systems for increasing EPS synthesis to influence moisture retention. Previous studies have shown that EPS increases the moisture retention in low-fat Mozzarella cheeses (Perry et al., 1997; Petersen et al., 2000). The average compositions of various low-fat Mozzarella cheeses are shown in Table 1. Control cheeses without EPS had the lowest moisture content (53.75\%). All cheeses containing EPS had significantly higher moisture contents compared with control cheeses $(P<$ $0.05)$. However, no significant difference in the moisture content was found between the EPS-containing cheeses 
Table 1. Average composition of low-fat Mozzarella cheeses $24 \mathrm{~h}$ after production (mean $\pm \mathrm{SE}$ ).

\begin{tabular}{llll}
\hline Cheese $^{1}$ & $\begin{array}{l}\text { Moisture (\%) } \\
(\mathrm{n}=9)\end{array}$ & $\begin{array}{l}\text { Fat }(\%) \\
(\mathrm{n}=6)\end{array}$ & $\begin{array}{l}\text { Protein }(\%) \\
(\mathrm{n}=9)\end{array}$ \\
\hline Control preacid & $53.75 \pm 0.14^{\mathrm{b}}$ & $6.13 \pm 0.06^{\mathrm{a}}$ & $32.75 \pm 0.34^{\mathrm{a}}$ \\
EPS preacid & $55.08 \pm 0.29^{\mathrm{a}}$ & $6.17 \pm 0.05^{\mathrm{a}}$ & $33.28 \pm 0.24^{\mathrm{a}}$ \\
$75: 25$ preacid & $54.79 \pm 0.43^{\mathrm{a}}$ & $6.13 \pm 0.06^{\mathrm{a}}$ & $32.70 \pm 1.42^{\mathrm{a}}$ \\
WPC preacid & $55.82 \pm 0.43^{\mathrm{a}}$ & $6.17 \pm 0.05^{\mathrm{a}}$ & $32.62 \pm 0.27^{\mathrm{a}}$ \\
\hline
\end{tabular}

a,b,c One-way ANOVA of means in a column with different superscript are significantly different $(P<0.05)$.

${ }^{1}$ Preacid $=$ Cheese milk preacidified to $\mathrm{pH} 6.1$ with citric acid; EPS $=$ starter culture containing capsular exopolysaccharides (EPS) produced by Streptococcus thermophilus 285; 75:25 = starter culture containing mixture of 75\% EPS-producing Strep. thermophilus 285 and $25 \%$ nonEPS Strep. thermophilus 1303; and WPC = cheeses made with whey protein concentrate and EPS-producing Strep. thermophilus 285.

$(P>0.05)$. Cheeses made with $100 \%$ EPS-producing Strep. thermophilus 285 had a moisture content of $55.08 \%$, whereas cheeses made with 75\% EPS-producing Strep. thermophilus 285 and 25\% nonEPS Strep. thermophilus 1303 contained 54.79\% moisture. Whey protein concentrate and EPS-containing cheeses had a moisture content of $55.82 \%$. Although the moisture content of EPS cheeses was significantly greater, the protein content remained similar between cheeses $(P>$ 0.05) (Table 1).

Table 2 shows the amount of EPS isolated from cheeses and curds, whey, stretch water, and milk collected during cheese making. Exopolysaccharide was absent in control cheeses made with EPS-negative strains. Cheeses made with EPS contained $41.18 \mathrm{mg}$ of EPS/g of cheese, and those containing WPC had 44.23 $\mathrm{mg}$ of EPS/g of cheese. The concentration of EPS was significantly lower in cheeses made by coculturing, at $28.61 \mathrm{mg} / \mathrm{g}(P<0.05)$. Although the amount of EPS in the cocultured cheeses was lower, it was sufficient to influence the moisture content. In the work by Zisu and
Shah (2003), a ropy EPS-producing strain was used. We anticipated that EPS concentrations would be lower if cocultured with capsule producing strains. The amount of capsular EPS synthesized is growth associated and is related to the number of bacterial cells present, as the capsules remain cell-bound. Due to lower inoculum volume, EPS levels were affected. It must be noted that the time allowed for the starter cultures to multiply before draining of whey was also shorter with preacidification of the milk than that during regular cheese making. Furthermore, the overall fermentation time during the cheese making $(\sim 0.5 \mathrm{~h})$ was critically shorter than that used in controlled fermentations $(24 \mathrm{~h})$ as reported earlier by Zisu and Shah (2003). Whey protein concentrate failed to increase the amount of EPS beyond levels recorded in EPS-only cheeses $(P>0.05)$ and this was reflected in the moisture content. Moisture retention did not increase. This was possibly attributed to pretreatment with citric acid that reduced time for the starter bacteria to multiply and the solubility of WPC. As previously stated, the addition of WPC to cheese milk was expected to increase the synthesis of EPS and, together with the moisture retention properties of the WPC, was expected to result in improved moisture content in cheeses. As shown in Table 2 , the protein content in cheeses made with WPC was not significantly higher than other cheeses $(P>$ 0.05). This is possibly due to metabolism of part of WPC by starter bacteria (Zisu and Shah, 2003). To achieve increased EPS synthesis in cheeses, the supplementation concentration of WPC should be increased.

Exopolysaccharide concentration in curd was similar to that found in cheeses $(P>0.05)$. The EPS level in stretch water was negligible and was not detected by the EPS extraction method adopted, suggesting that the majority of EPS remained within the cheese protein matrix after draining of the whey. A considerable

Table 2. Exopolysaccharide isolated from cheese, curd, whey, stretch water, and milk $24 \mathrm{~h}$ after production $(\mathrm{n}=6)($ mean $\pm \mathrm{SE})$.

\begin{tabular}{|c|c|c|c|c|}
\hline \multirow[b]{2}{*}{ Sample } & \multicolumn{4}{|c|}{ Cheese $^{1}$} \\
\hline & Control & EPS & $75: 25$ & WPC \\
\hline Cheese (mg/g) & $\mathrm{ND}^{\mathrm{c}, \mathrm{A}, 2}$ & $41.18 \pm 1.21^{\mathrm{a}, \mathrm{A}}$ & $28.61 \pm 1.71^{\mathrm{b}, \mathrm{A}}$ & $44.23 \pm 3.16^{\mathrm{a}, \mathrm{A}}$ \\
\hline Curd (mg/g) & $\mathrm{ND}^{\mathrm{c}, \mathrm{A}}$ & $38.14 \pm 2.21^{\mathrm{a}, \mathrm{A}}$ & $28.16 \pm 1.24^{\mathrm{b}, \mathrm{A}}$ & $42.73 \pm 5.30^{\mathrm{a}, \mathrm{AB}}$ \\
\hline Whey $(\mathrm{mg} / \mathrm{mL})$ & $\mathrm{ND}^{\mathrm{b}, \mathrm{A}}$ & $19.80 \pm 2.33^{\mathrm{a}, \mathrm{B}}$ & $18.13 \pm 3.33^{\mathrm{a}, \mathrm{B}}$ & $28.36 \pm 4.98^{\mathrm{a}, \mathrm{B}}$ \\
\hline Stretch water $(\mathrm{mg} / \mathrm{mL})$ & $\mathrm{ND}^{\mathrm{a}, \mathrm{A}}$ & $\mathrm{ND}^{\mathrm{a}, \mathrm{CD}}$ & $\mathrm{ND}^{\mathrm{a}, \mathrm{CD}}$ & $\mathrm{ND}^{\mathrm{a}, \mathrm{CD}}$ \\
\hline Milk (mg/mL) & $\mathrm{ND}^{\mathrm{a}, \mathrm{A}}$ & $\mathrm{ND}^{\mathrm{a}, \mathrm{D}}$ & $\mathrm{ND}^{\mathrm{a}, \mathrm{D}}$ & $\mathrm{ND}^{\mathrm{a}, \mathrm{D}}$ \\
\hline \multicolumn{5}{|c|}{$\begin{array}{l}\text { a,b,c One-way ANOVA of means across a row and }{ }^{\mathrm{A}, \mathrm{B}, \mathrm{C}} \text { one-way ANOVA of means in a column with different } \\
\text { uperscript are significantly different }(P<0.05) \text {. }\end{array}$} \\
\hline \multicolumn{5}{|c|}{$\begin{array}{l}{ }^{1} \text { Control = Cheese milk preacidified to } \mathrm{pH} 6.1 \text { with citric acid; EPS = starter culture containing capsular } \\
\text { exopolysaccharides (EPS) produced by Streptococcus thermophilus } 285 ; 75: 25=\text { starter culture containing } \\
\text { mixture of } 75 \% \text { EPS-producing Strep. thermophilus } 285 \text { and } 25 \% \text { nonEPS Strep. thermophilus } 1303 \text {; and } \\
\text { WPC = cheeses made with whey protein concentrate and EPS-producing Strep. thermophilus } 285 \text {. }\end{array}$} \\
\hline
\end{tabular}


Table 3. Calcium content in cheese, curd, whey, stretch water, and milk $24 \mathrm{~h}$ after production ( $\mathrm{n}=6$ to 12) (mean $\pm \mathrm{SE}$ ).

\begin{tabular}{llrrr}
\hline & \multicolumn{4}{c}{ Cheese $^{1}$} \\
\cline { 2 - 5 } Sample & \multicolumn{1}{c}{$\begin{array}{l}\text { Control } \\
(\mathrm{mg} / 100 \mathrm{~g})\end{array}$} & $\begin{array}{l}\text { EPS } \\
(\mathrm{mg} / 100 \mathrm{~g})\end{array}$ & $\begin{array}{l}75: 25 \\
(\mathrm{mg} / 100 \mathrm{~g})\end{array}$ & \multicolumn{1}{l}{$\begin{array}{l}\text { WPC } \\
(\mathrm{mg} / 100 \mathrm{~g})\end{array}$} \\
\hline Cheese & $1041.37 \pm 11.52^{\mathrm{a}}$ & $1041.34 \pm 9.28^{\mathrm{a}}$ & $1075.77 \pm 14.94^{\mathrm{a}}$ & $1044.50 \pm 12.61^{\mathrm{a}}$ \\
Curd & $924.88 \pm 24.76^{\mathrm{a}}$ & $926.97 \pm 25.82^{\mathrm{a}}$ & $991.46 \pm 25.59^{\mathrm{a}}$ & $950.84 \pm 19.39^{\mathrm{a}}$ \\
Whey & $32.81 \pm 0.45^{\mathrm{d}}$ & $34.60 \pm 0.37^{\mathrm{c}}$ & $36.47 \pm 0.36^{\mathrm{b}}$ & $38.84 \pm 0.42^{\mathrm{a}}$ \\
Stretch water & $14.61 \pm 0.42^{\mathrm{a}}$ & $11.32 \pm 0.20^{\text {cd }}$ & $10.96 \pm 0.31^{\mathrm{d}}$ & $11.80 \pm 0.07^{\mathrm{b}}$ \\
Milk & $95.10 \pm 0.87^{\mathrm{a}}$ & $93.29 \pm 2.26^{\mathrm{a}}$ & $92.96 \pm 2.67^{\mathrm{a}}$ & $99.54 \pm 2.57^{\mathrm{a}}$ \\
\hline
\end{tabular}

${ }^{\text {a,b,c } O n e-w a y ~ A N O V A ~ o f ~ m e a n s ~ a c r o s s ~ a ~ r o w ~ w i t h ~ d i f f e r e n t ~ s u p e r s c r i p t ~ a r e ~ s i g n i f i c a n t l y ~ d i f f e r e n t ~}(P<0.05)$.

${ }^{1}$ Control $=$ Cheese milk preacidified to $\mathrm{pH} 6.1$ with citric acid; EPS = starter culture containing capsular exopolysaccharides (EPS) produced by Streptococcus thermophilus 285; 75:25 = starter culture containing mixture of 75\% EPS-producing Strep. thermophilus 285 and 25\% nonEPS Strep. thermophilus 1303; and $\mathrm{WPC}=$ cheeses made with whey protein concentrate and EPS-producing Strep. thermophilus 285.

amount of EPS was retrieved from whey samples (18 to $28 \mathrm{mg} / \mathrm{mL}$ ) because large numbers of starter culture cells were drained in the whey. Despite the loss into whey, the increase in the EPS concentration remained significantly higher in cheeses $(P<0.05)$. No EPS was detected in milk; hence, the build up in the EPS concentration occurred during the cheese making process.

The fat and calcium (Table 3) contents were similar between cheeses and curds $(P>0.05)$. The influence of fat and calcium on moisture retention, texture, and functionality of cheeses were expected to be negligible. Whey protein concentrate caused some variation in the calcium content of milk, as this mineral was present in the product. However, the difference in calcium concentration upon addition of WPC was insignificant $(P>$ $0.05)$. There was a minor but insignificant difference in the concentration of calcium in stretching water and whey.

\section{Meltability}

Figure 1 presents the changes in meltability of lowfat Mozzarella cheeses over $45 \mathrm{~d}$ of storage at $4^{\circ} \mathrm{C}$. All cheeses exhibited a significant increase in meltability between $\mathrm{d} 7$ and $45(P<0.05)$ because of proteolysis and degradation of the milk protein matrix (Fife et al., 1996). The control cheeses made with preacidified milk and nonEPS cultures displayed the lowest meltability $(P<0.05)$ at $\mathrm{d} 7$, at $30.10 \mathrm{~mm}$. Melt distance increased from 23.07 to $53.18 \mathrm{~mm}$ at d $45(P<0.05)$. This represented similar meltability to WPC cheeses $(48.86 \mathrm{~mm})$ $(P>0.05)$, and EPS cheeses $(55.78 \mathrm{~mm})(P>0.05)$ at $\mathrm{d} 45$. The meltability of cocultured cheeses remained higher after $45 \mathrm{~d}$ of maturation $(60.54 \mathrm{~mm})(P<0.05)$. It was also observed that the control cheeses maintained a gradual increase in meltability at each sampling time, whereas cheeses containing EPS showed a significant increase in melt distance between d 14 and 28 only ( $P$ $<0.05)$.
Meltability of preacidified cheeses containing EPS was $42.03 \mathrm{~mm}$ at $\mathrm{d}$ 7. Meltability was greater than the control cheeses that were also preacidified at $d 7$ and $28(P<0.05)$. Other researchers have shown that EPS increases the meltability of low-fat Mozzarella cheeses due to greater moisture retention (Perry et al., 1997, 1998; Petersen et al., 2000). By d 45, melt distance increased from 13.75 to $55.78 \mathrm{~mm}$; however, this was similar to that of the control cheeses at $d 45$. In a separate study, no significant difference was recorded in the melt distance between cheeses made with nonEPS and EPS cultures in the absence of an acid treatment (Zisu and Shah, 2002).

The meltability of cheeses made with coculturing of EPS- and nonEPS-producing strains of Strep. thermophilus was similar to that of EPS cheeses during the first $14 \mathrm{~d}$ of storage $(P>0.05)$. At $\mathrm{d} 7$, a melt of 47.13 $\mathrm{mm}$ was recorded. At d 28 and 45 , meltability was greatest in cocultured cheeses $(P<0.05)$, reaching 62.04 and $60.54 \mathrm{~mm}$, respectively. A substantial increase in the melt distance (an increase by $13.41 \mathrm{~mm}$ ) of cocultured cheeses was likely to be due to greater proteolysis over time (Zisu and Shah, accepted).

Cheeses containing WPC had a melt distance of 41.61 $\mathrm{mm}$ at $\mathrm{d} 7$. This was greater than that of control cheeses $(P<0.05)$ at $d 7$. No significant difference existed between the 2 types of cheeses at d 14, 28, and 45 ( $P>$ $0.05)$. Cheeses containing WPC were expected to show greater meltability resulting from the combined effects of increased moisture retention of EPS and due to preacidification that reduced the calcium-casein interactions and stimulated primary proteolysis. This did not, however, occur. Meltability increased by only $7.25 \mathrm{~mm}$ over $45 \mathrm{~d}$ of storage to $48.86 \mathrm{~mm}$. The poor performance of cheeses containing WPC over time indicates that WPC may have interfered with the physical ability of the cheese to flow when melted. This hypothesis needs further investigation. 


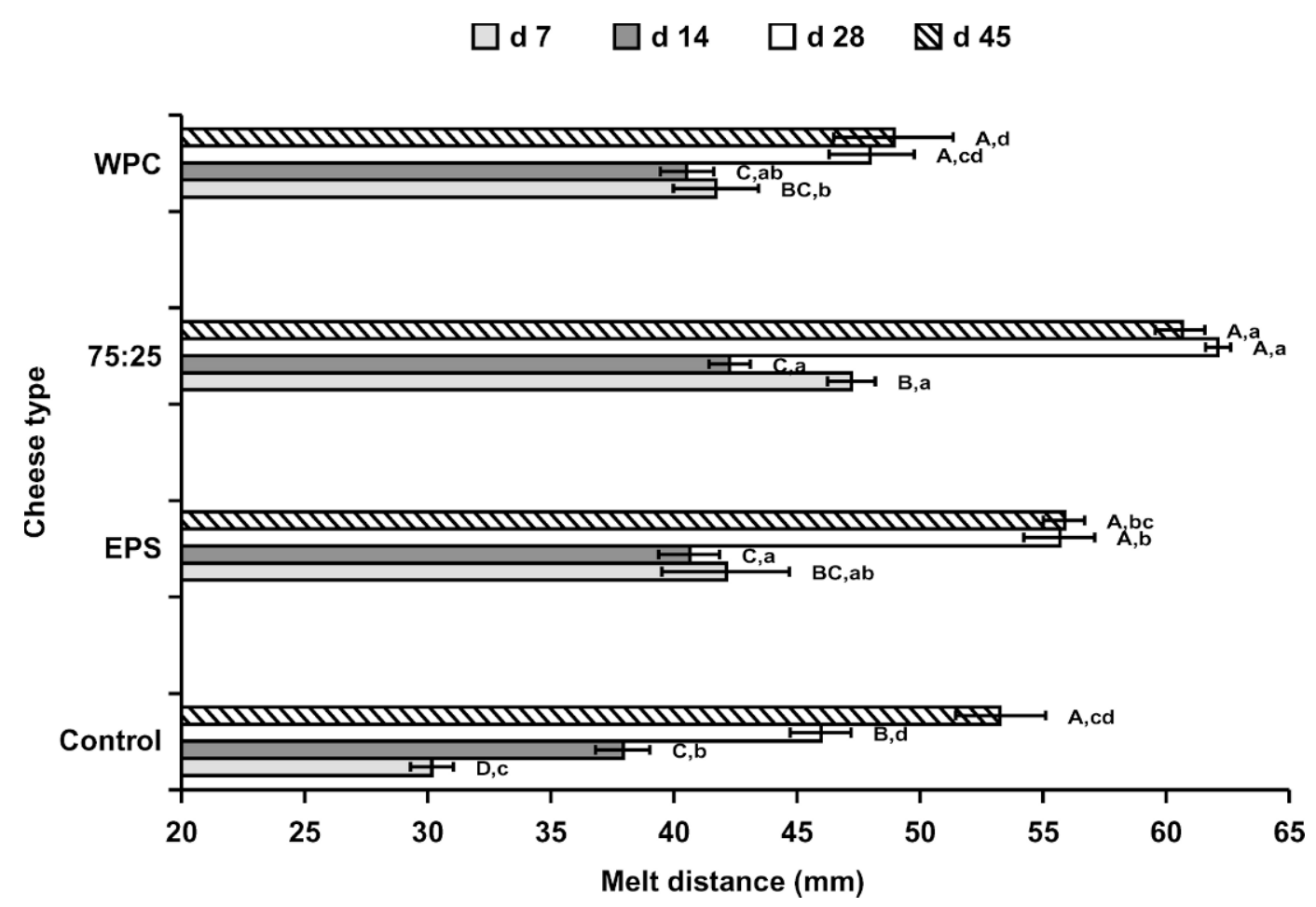

Figure 1. Cheese melt of control (cheese milk preacidified to $\mathrm{pH}$ 6.1), EPS (capsular exopolysaccharides produced by Streptococcus thermophilus 285) preacidified, 75:25 (mixture of 75\% EPS-producing Strep. thermophilus 285 and 25\% nonEPS Strep. thermophilus 1303) preacidified, and WPC (whey protein concentrate and EPS-producing Strep. thermophilus 285) preacidified cheeses over $45 \mathrm{~d}$ of storage at $4^{\circ} \mathrm{C} .{ }^{\mathrm{ABC}}$ One-way ANOVA of means $(\mathrm{n}=6$; errors $\pm \mathrm{SE}$ ) between all time periods within a cheese type, and abcone-way ANOVA of means at d 7, 14, 28, and 45 between cheese types with different superscript are significantly different $(P<0.05)$.

\section{Texture Profile Analysis}

Cheese hardness. Figure 2 illustrates the changes in hardness in cheeses over $45 \mathrm{~d}$ of storage at $4^{\circ} \mathrm{C}$. Hardness decreased between $\mathrm{d} 7$ and 45 in all cheese types except in those made with WPC. A reduction in hardness is possibly due to the proteolysis of the protein matrix. Control preacidified cheeses were hardest in general. The overall hardness was reduced by preacidification of milk and introducing EPS-producing starter bacteria alone, and as a coculture. Hassan and Frank (1997) showed that curd tension and firmness of nonfat curd was reduced and was comparable to a full-fat rennet curd (containing $40 \mathrm{~g}$ of fat/L) using EPS capsule forming Strep. thermophilus culture. At $45 \mathrm{~d}$ of maturation, the EPS and EPS-cocultured cheeses were softer than the control $(P<0.05)$. The cheeses made with EPS cultures and EPS coculture, however, showed similar hardness $(P>0.05)$.

At d 7, WPC and EPS cheeses were softest due to the presence of EPS and WPC particles possibly disrupting the protein matrix, allowing the protein network to become less compact. Between 7 and 45, cheese hardness remained similar $(P>0.05)$, whereas the cheeses made with EPS and EPS-coculture became comparably softer. Cheeses made with WPC remained softer than the control cheeses at all sampling times.

Cheese cohesiveness. Figure 3 shows cohesiveness of cheeses over $45 \mathrm{~d}$ of storage at $4^{\circ} \mathrm{C}$. Cohesiveness was similar between cheeses made with EPS-producing starter bacteria, and there was no change within a cheese type over $45 \mathrm{~d}$ of storage $(P>0.05)$. The composition between each type of cheese varied little, particularly in the protein and moisture contents, hence the similarity in cohesiveness. The overall cohesiveness was lower in control, preacidified cheeses without EPS and reduced moisture content (Table 1). Previous findings suggest that the strength of the internal bonds of the product that represent cohesiveness reduced over lengthy storage in cheeses with higher moisture content and preacidification (Zisu and Shah, accepted).

Cheese springiness. Figure 4 represents springiness in cheeses over $45 \mathrm{~d}$ of storage as the height recovered after deformation. Springiness was greatest in control cheeses at d 28 and 45 . These were also the hardest cheeses with the lowest moisture and cohesiveness. All cheeses maintained their structural integrity to resist permanent deformation, and springiness remained unchanged throughout storage between $\mathrm{d} 7$ and 45 ( $P$ $>0.05)$. 


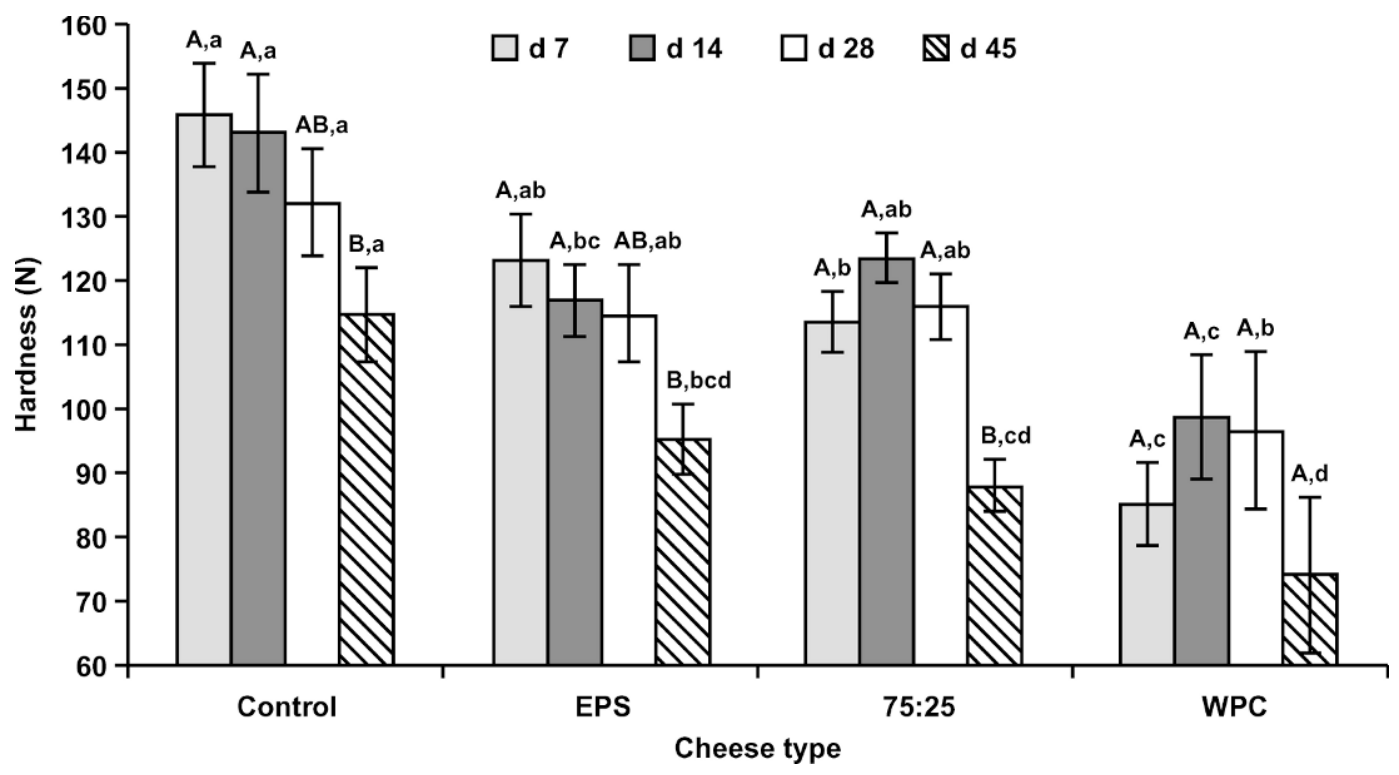

Figure 2. Hardness of control (cheese milk preacidified to $\mathrm{pH}$ 6.1), EPS (capsular exopolysaccharides produced by Streptococcus thermophilus 285) preacidified, 75:25 (mixture of 75\% EPS-producing Strep. thermophilus 285 and 25\% nonEPS Strep. thermophilus 1303) preacidified, and WPC (whey protein concentrate and EPS-producing Strep. thermophilus 285) preacidified cheeses over $45 \mathrm{~d}$ of storage at $4^{\circ} \mathrm{C}$. ${ }^{\mathrm{ABC}} \mathrm{One}-$ way ANOVA of means $\left(n=9\right.$; errors \pm SE) between all time periods within a cheese type, and ${ }^{\text {abc }}$ one-way ANOVA of means at $d 7,14,28$, and 45 between cheese types with different superscript are significantly different $(P<0.05)$.

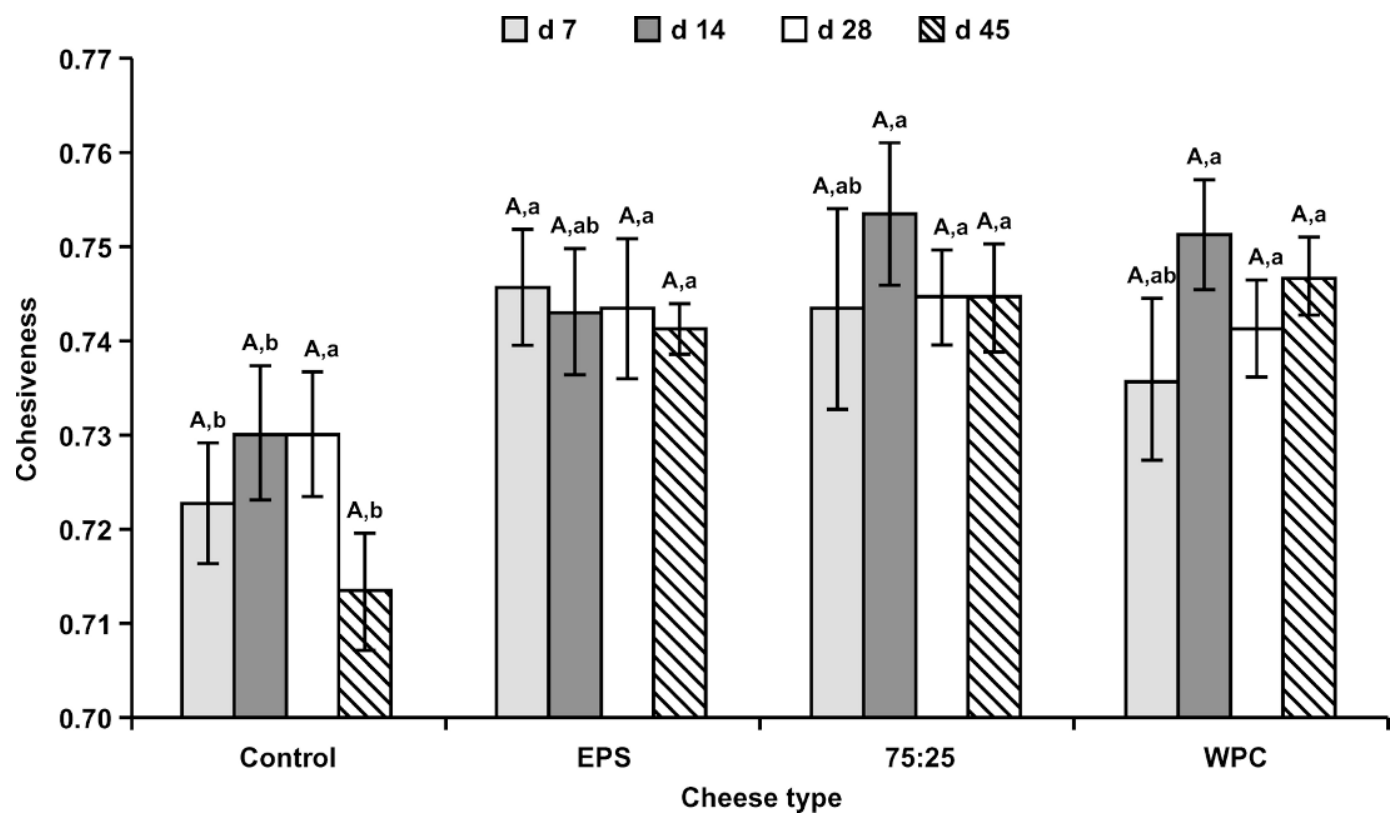

Figure 3. Cohesiveness of control (cheese milk preacidified to $\mathrm{pH}$ 6.1), EPS (capsular exopolysaccharides produced by Streptococcus thermophilus 285) preacidified, 75:25 (mixture of 75\% EPS-producing Strep. thermophilus 285 and 25\% nonEPS Strep. thermophilus 1303) preacidified, and WPC (whey protein concentrate and EPS-producing Strep. thermophilus 285) preacidified cheeses over $45 \mathrm{~d}$ of storage at $4{ }^{\circ} \mathrm{C}$. ${ }^{\mathrm{ABC}}$ One-way ANOVA of means $\left(\mathrm{n}=9\right.$; errors $\pm \mathrm{SE}$ ) between all periods within a cheese type, and ${ }^{\text {abc }}$ one-way ANOVA of means at $\mathrm{d} 7$, 14,28 , and 45 between cheese types with different superscript are significantly different $(P<0.05)$. 


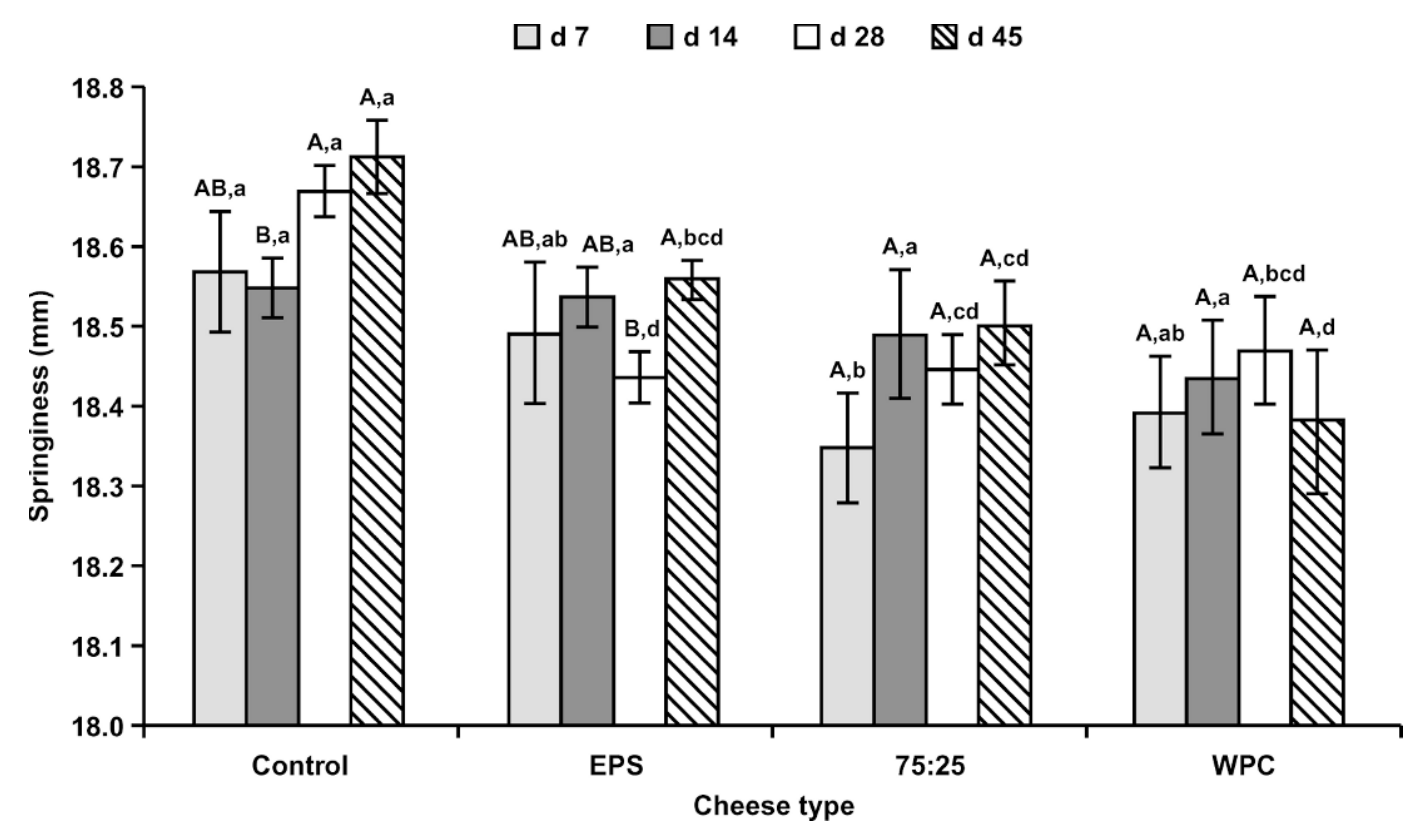

Figure 4. Springiness of control (cheese milk preacidified to $\mathrm{pH}$ 6.1), EPS (capsular exopolysaccharides produced by Streptococcus thermophilus 285) preacidified, 75:25 (mixture of 75\% EPS-producing Strep. thermophilus 285 and 25\% nonEPS Strep. thermophilus 1303) preacidified, and WPC (whey protein concentrate and EPS-producing Strep. thermophilus 285) preacidified cheeses over $45 \mathrm{~d}$ of storage at $4^{\circ} \mathrm{C} .{ }^{\mathrm{ABC}}$ One-way ANOVA of means $(\mathrm{n}=9$; errors $\pm \mathrm{SE})$ between all periods within a cheese type, and ${ }^{\text {abc }}$ one-way ANOVA of means at $\mathrm{d}$ 7, 14, 28, and 45 between cheese types with different superscript are significantly different $(P<0.05)$.

Cheese chewiness. The chewiness of cheeses is a measure of the primary textural parameters and is closely related to the hardness of the product. Figure 5 represents the chewiness of cheeses calculated as hardness $\times$ cohesiveness $\times$ springiness. Control cheeses having the lowest moisture content and the highest springiness at $\mathrm{d} 28$ and 45 generally exhibited more chewiness than those made with EPS-producing Strep.

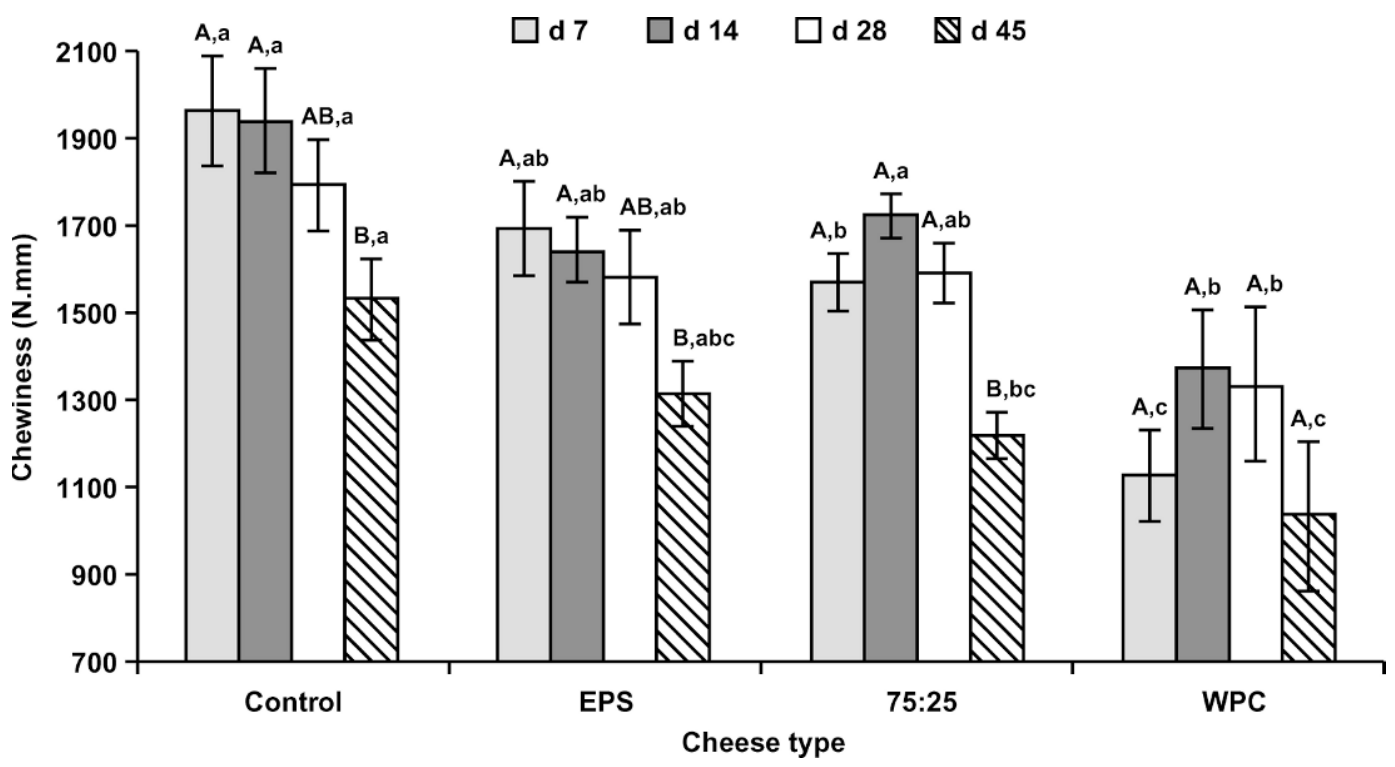

Figure 5. Chewiness of control (cheese milk preacidified to $\mathrm{pH}$ 6.1), EPS (capsular exopolysaccharides produced by Streptococcus thermophilus 285) preacidified, 75:25 (mixture of 75\% EPS-producing Strep. thermophilus 285 and 25\% nonEPS Strep. thermophilus 1303) preacidified, and WPC (whey protein concentrate and EPS-producing Strep. thermophilus 285) preacidified cheeses over $45 \mathrm{~d}$ of storage at $4^{\circ} \mathrm{C}$. ${ }^{\mathrm{ABC}}$ Oneway ANOVA of means $\left(n=9\right.$; errors \pm SE) between all periods within a cheese type and ${ }^{\text {abc }}$ one-way ANOVA of means at d $7,14,28$ and 45 between cheese types with different superscript are significantly different $(P<0.05)$. 


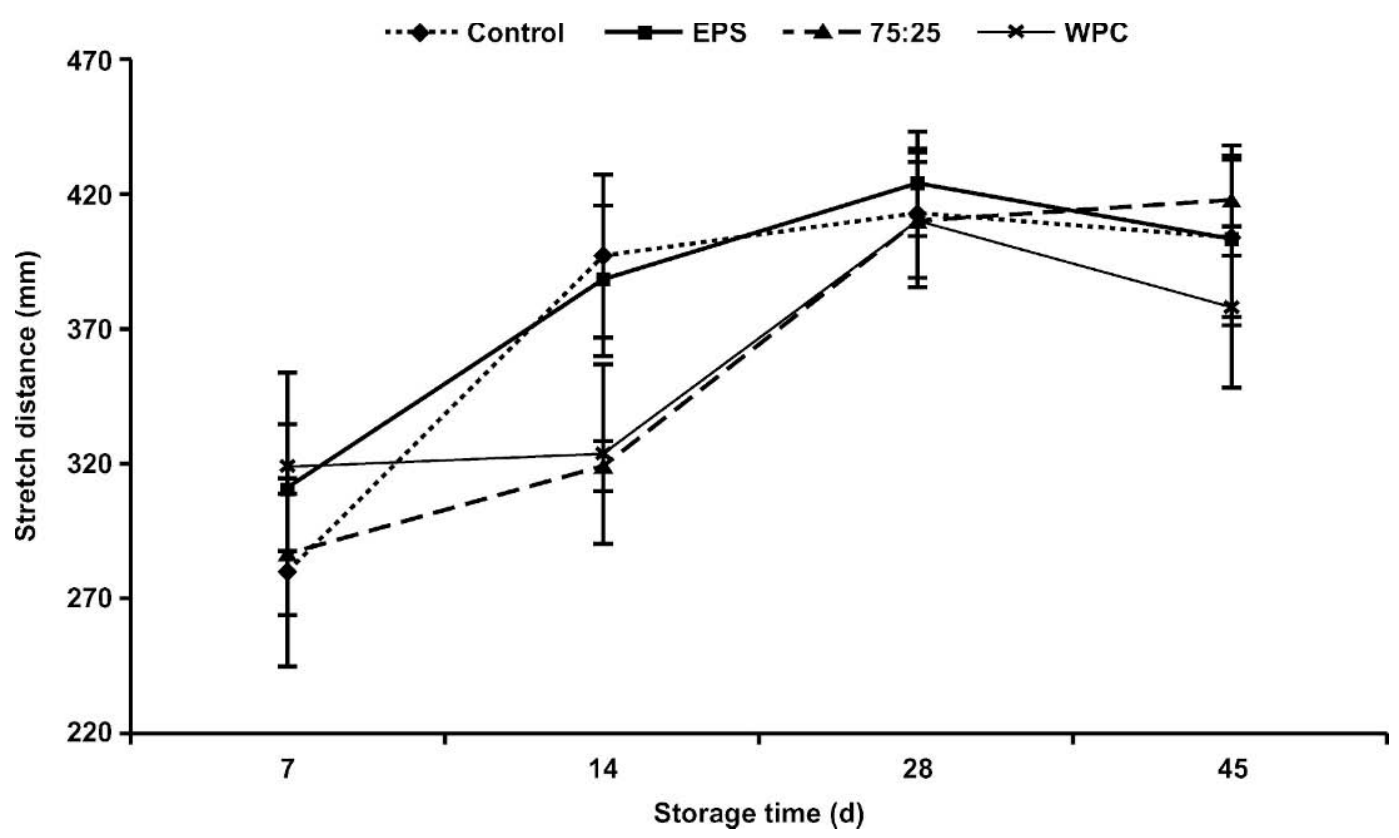

Figure 6. Stretch characteristics of control (cheese milk preacidified to $\mathrm{pH}$ 6.1) ( ), EPS (capsular exopolysaccharides produced by Streptococcus thermophilus 285) preacidified, (口), 75:25 (mixture of 75\% EPS-producing Strep. thermophilus 285 and $25 \%$ nonEPS Strep. thermophilus 1303) preacidified, (A) and WPC (whey protein concentrate and EPS-producing Strep. thermophilus 285) preacidified ( $\times$ ) cheeses over $45 \mathrm{~d}$ of storage at $4^{\circ} \mathrm{C},(\mathrm{n}=6$; errors $\pm \mathrm{SE})$.

thermophilus. Exopolysaccharide and cocultured cheeses exhibited similar chewiness at all sampling times $(P>0.05)$. All cheeses except those containing WPC tended to show a decrease in chewiness over time. The reduction was not significant until d $45(P<0.05)$. Chewiness appeared to be lower in cheeses made with WPC; however, chewiness was statistically similar to those made with EPS at d 14, 28, and 45 and coculturing at $\mathrm{d} 28$ and $45(P>0.05)$. Cheeses containing WPC showed no changes in chewiness over $45 \mathrm{~d}$ of storage $(P>0.05)$.

\section{Cheese Stretchability}

The stretchability pattern of cheeses over $45 \mathrm{~d}$ of storage at $4^{\circ} \mathrm{C}$ is shown in Figure 6 . Stretchability was lowest at $\mathrm{d} 7 \mathrm{in}$ all batches of cheese $(P<0.05)$. All types of cheeses showed an increase in stretch distance over time between $\mathrm{d} 7$ and $28(P<0.05)$. Stretchability was similar between cheese types at d 7, 28, and 45 . At d 14, cheeses made with WPC and EPS and coculture had a lower stretchability than EPS and control cheeses. Control, preacidified cheeses showed a significant increase in stretch distance between d $7(279 \mathrm{~mm})$ and d $14(396 \mathrm{~mm})(P<0.05)$. Between d $14(396 \mathrm{~mm})$ and d $45(404 \mathrm{~mm})$, there was no significant change in the stretch distance $(P>0.05)$.

Cheeses made with EPS, EPS coculture, and WPC did not show a substantial increase in the melt distance between $\mathrm{d} 7(310,286$, and $319 \mathrm{~mm}$, respectively) and d $14(387,318$, and $323 \mathrm{~mm}$, respectively) $(P>0.05)$. Stretchability increased significantly between $\mathrm{d} 14$ and d 28 (423, 410, and $410 \mathrm{~mm}$, respectively) $(P<0.05)$, and remained similar at $d 45(402,417$, and $378 \mathrm{~mm}$, respectively).

Based on our observations, control and WPC cheeses were exceptionally tough at $d 7$, causing several test samples to lift away from the bottom of the sample beaker when stretched. Control cheeses appeared to have stabilized at d 14 and beyond and stretching was possible. Whey protein concentrate cheeses also had a good stretch appearance at $d 14$, characteristic of the full-fat variety, however, they became excessively soft and pasty when melted after $28 \mathrm{~d}$. Cheeses made with EPS and EPS coculture exhibited a good stretch appearance throughout storage, typical to that observed in high-fat cheeses. Our work with EPS and fat replacers suggests that a loss in stretch distance with time due to increase in protein breakdown associated with maintaining the structure was expected beyond d 45 (Zisu and Shah, accepted).

\section{Pizza Bake}

Results from the simulated pizza bake tests at $\mathrm{d} 28$ and 45 are shown in Figure 7. The browning behavior, melt, and flow of cheese shreds when baked were evaluated according to the methods of other researchers $(\mathrm{Ru}-$ 


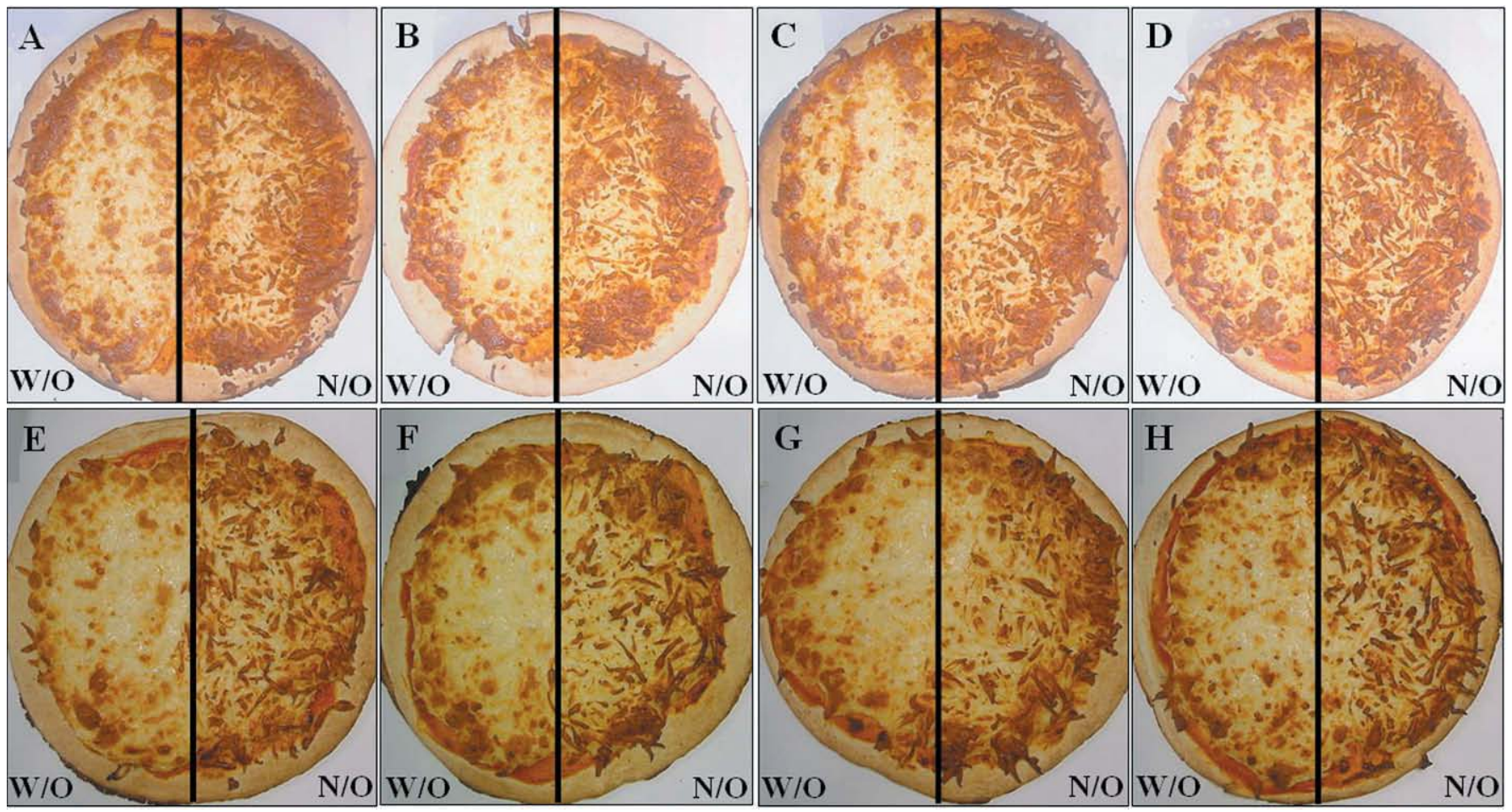

Figure 7. Pizza bake characteristics of control preacidified cheeses (cheese milk preacidified to $\mathrm{pH}$ 6.1) at d 28 and d 45 , respectively (A and E), EPS (capsular exopolysaccharides produced by Streptococcus thermophilus 285) preacidified cheeses (B and F), 75\% (EPS Strep. thermophilus):25\% (nonEPS Strep. thermophilus) cocultured and preacidified cheeses (C and G), and WPC (whey protein concentrate and EPS Strep. thermophilus 285) preacidified cheeses (D and H). W/O = With oil; N/O = No oil.

dan and Barbano, 1998a,b; Metzger et al., 2000a). The hydrophobic barrier concept applied to low-fat cheese shreds was introduced by Rudan and Barbano (1998a,b), as it was found to prevent surface moisture loss to reduce surface scorching and to allow adequate shred fusion and melt. At d 28, all 4 batches of cheeses showed scorching, and lacked shred fusion and adequate melt in the absence of an external coating of canola oil. An application of canola oil to coat the surface of the cheese shreds before baking resulted in improved cheese fusion and melt and reduced scorching by lowering moisture loss from the shred surface (Rudan and Barbano, 1998b). Exopolysaccharide and preacidified cheeses showed the best bake characteristics with larger white, nonscorched portions toward the middle of the pizza (Figure 7B). Excessive burning continued to occur around edges of the pizza where more evaporation took place. Control and cocultured cheeses (Figure 7A and $7 \mathrm{C}$, respectively) were similar in appearance, whereas WPC-containing cheeses (Figure 7D) exhibited the most scorching, creating a blister-like appearance. When heated, WPC cheeses appeared to have low heat stability as discussed earlier in the sections related to cheese melt and stretch.
By d 45, a substantial improvement in meltability, flow, shred fusion, and reduced blistering was evident for all 4 types of cheeses. Control, EPS, and coculture cheeses (Figure 7E, F, and G, respectively) appeared acceptable when coated with oil based on meltability, flow, shred fusion, and reduction in blistering. Cheeses made with WPC (Figure 7H) continued to show more surface browning than other cheeses.

L-values before cooking. Table 4 shows L-values as a measure of cheese whiteness before cooking, after cooking when warm, and after cooling of cheeses baked at $d 28$ and 45 of storage. Due to the similarity in cheese composition, L-values were generally similar among cheese types before cooking.

L-values after cooking (warm). Whiteness generally increased immediately after baking (Table 4). When cheese shreds were coated with oil, L-values were greater at d 28 and 45 in control and EPS cheeses $(P$ $<0.05$ ). At d 28, cheeses made with coculturing at a ratio of 75:25 of EPS to nonEPS Strep. thermophilus and those made with WPC showed similar readings between oil-coated and noncoated shreds within each cheese type $(P>0.05)$. A high degree of scorching was evident in these cheeses at this time. At d 45 , as surface 
scorching was reduced, L-values became greater for oilcoated cheeses $(P<0.05)$.

Surface scorching was most reduced and shred fusion was most improved in EPS cheeses. Between d 28 and d 45, L-values were significantly higher for both the oil-coated and noncoated cheeses $(P<0.05)$. The control cheeses and those made using coculturing recorded a substantial improvement when coated with oil $(P<$ $0.05)$, but not in the untreated batch $(P>0.05)$. Cheeses made with WPC, although showing improved melt and flow, did not show greater whiteness between $\mathrm{d} 28$ and $45(P>0.05)$. The lactose content of WPC 392 is typically $6.7 \%$. Lactose was likely a contributing factor in blistering and reduced whiteness. As a reducing sugar, lactose will react in the presence of amino acids leading to nonenzymatic browning. Due to moisture loss that occurs during baking from the surface of cheese shreds not coated in oil, as described by Rudan and Barbano (1998b), shred fusion remained a problem. Surface scorching was severe, L-values remained low, and cheeses were not acceptable after baking. An external oil coating remained necessary for all cheese types.

L-values after cooking (cool). L-Values were generally lower after cooling and all cheeses became translucent and shiny in appearance. Cheeses containing WPC, however, showed similar L-values after cooling as the warm counterpart. The oil-coated cheeses continued to show significantly higher L-values at d 28 and 45 than those lacking an oil coating $(P<0.05)$.

\section{CONCLUSIONS}

The moisture content of control (preacidified) lowfat Mozzarella cheeses was lowest. Moisture retention increased with the use of capsular EPS-producing Strep. thermophilus 285 when used as a starter culture singly, as a coculture with nonEPS Strep. thermophilus, or in the presence of WPC. Exopolysaccharide also improved the textural and functional characteristics of cheeses by reducing hardness and increasing meltability. Cheeses showed a high level of scorching and incomplete shred fusion when baked on a pizza base unless cheese shreds were coated with oil. Coculturing an EPSproducing Strep. thermophilus with a nonEPS-producing strain and the use of WPC did not increase EPS synthesis during cheese manufacture compared with those made with EPS-only cultures. A significant amount of EPS was lost through the whey. Streptococcus thermophilus 285 used as a coculture limited the amount of EPS produced in cheeses; however, coculturing led to greater meltability and softer texture. On the contrary, the use of the WPC in cheeses interfered with meltability, texture, and surface scorching during pizza baking. 


\section{ACKNOWLEDGMENTS}

We thank the Australian Research Council-Strategic Partnership with Industry for Research and Training Scheme for funding this project. We also thank Gary Harvey at Dairy Farmers, Tingalpa, Queensland, Australia, for the ongoing support of this research.

\section{REFERENCES}

AOAC. 1999. Official Methods of Analysis. Vol. 2. 16th ed. AOAC International, Gaithersburg, MD.

Bhaskaracharya, R. K., and N. P. Shah. 1999. Texture evaluation of commercial Mozzarella cheese. Aust. J. Dairy Technol. 54:36-40.

Bhaskaracharya, R. K., and N. P. Shah. 2002. A new method for measuring stretchability of low-fat Mozzarella cheese. Aust. J. Dairy Technol. 57:169.

De Vuyst, L., and B. Degeest. 1999. Heteropolysaccharides from lactic acid bacteria. FEMS Microbiol. Rev. 23:153-177.

Feeney, E. P., T. P. Guinee, and P. F. Fox. 2002. Effect of $\mathrm{pH}$ and calcium concentration on proteolysis in Mozzarella cheese. J. Dairy Sci. 85:1646-1654.

Fife, R. L., D. J. McMahon, and C. J. Oberg. 1996. Functionality of low fat Mozzarella cheese. J. Dairy Sci. 79:1903-1910.

Guinee, T. P., E. P. Feeney, M. A. E. Auty, and P. F. Fox. 2002. Effect of $\mathrm{pH}$ and calcium concentration on some textural and functional properties of Mozzarella cheese. J. Dairy Sci. 85:1655-1669.

Hassan, A. N., M. Corredig, and J. F. Frank. 2002. Capsule formation by nonropy starter cultures affects the viscoelastic properties of yogurt during structure formation. J. Dairy Sci. 85:716-720.

Hassan, A. N., and J. F. Frank. 1997. Modification of microstructure and texture of rennet curd by using a capsule-forming non-ropy lactic culture. J. Dairy Res. 64:115-121.

Hassan, A. N., J. F. Frank, K. A. Schmidt, and S. I. Shalabi. 1996a. Rheological properties of yogurt made with encapsulated nonropy lactic cultures. J. Dairy Sci. 79:2091-2097.

Hassan, A. N., J. F. Frank, K. A. Schmidt, and S. I. Shalabi. 1996b. Textural properties of yogurt made with encapsulated nonropy lactic cultures. J. Dairy Sci. 79:2098-2130.

Joshi, N. S., K. Muthukumarappan, and R. I. Dave. 2003. Understanding the role of calcium in functionality of part skim Mozzarella cheese. J. Dairy Sci. 86:1918-1926.

Low, D., J. A. Ahlgren, D. Horne, D. J. McMahon, C. J. Oberg, and J. R. Broadbent. 1998. Role of Streptococcus thermophilus MR-1C capsular exopolysaccharide in cheese moisture retention. Appl. Environ. Microbiol. 64:2147-2151.

Marshall, V. M., and H. L. Rawson. 1999. Effects of exopolysaccharide-producing strains of thermophilic lactic acid bacteria on the texture of stirred yoghurt. Int. J. Food Sci. Technol. 34:137-143.

McMahon, D. J., M. C. Alleyne, R. L. Fife, and C. J. Oberg. 1996. Use of fat replacers in low fat Mozzarella cheese. J. Dairy Sci. 79:1911-1921.
McMahon, D. J., and C. J. Oberg. 1998. Influence of fat, moisture and salt on functional properties of Mozzarella cheese. Aust. J. Dairy Technol. 53:98-101.

Metzger, L. E., D. M. Barbano, M. A. Rudan, P. S. Kindstedt, and M. R. Guo. 2000a. Whiteness changes during heating and cooling of Mozzarella cheese. J. Dairy Sci. 83:1-10.

Metzger, L. E., M. A. Rudan, and P. S. Kindstedt. 2000b. Effect of milk preacidification on low fat Mozzarella cheese. 1. Composition and yield. J. Dairy Sci. 83:648-658.

Paulson, B. M., D. J. McMahon, and C. J. Oberg. 1998. Influence of sodium chloride on appearance, functionality, and protein arrangements in nonfat Mozzarella cheese. J. Dairy Sci. 81:2053-2064.

Perry, D. M., D. J. McMahon, and C. J. Oberg. 1997. Effect of exopolysaccharide-producing cultures on moisture retention in low fat Mozzarella cheese. J. Dairy Sci. 80:799-805.

Perry, D. M., D. J. McMahon, and C. J. Oberg. 1998. Manufacture of low fat Mozzarella cheese using exopolysaccharide-producing starter cultures. J. Dairy Sci. 81:563-566.

Petersen, B. L., R. I. Dave, D. J. McMahon, C. J. Oberg, and J. R. Broadbent. 2000. Influence of capsular and ropy exopolysaccharide-producing Streptococcus thermophilus on Mozzarella cheese and cheese whey. J. Dairy Sci. 83:1952-1956.

Poduval, V. S., and V. V. Mistry. 1999. Manufacture of reduced fat Mozzarella cheese using ultrafiltered sweet buttermilk and homogenized cream. J. Dairy Sci. 82:1-9.

Pons, M., and S. M. Fiszman. 1996. Instrumental texture profile analysis with particular reference to gelled systems. J. Texture Stud. 27:597-624.

Rawson, H. L., and V. M. Marshall. 1997. Effect of 'ropy' strains of Lactobacillus delbrueckii ssp. bulgaricus and Streptococcus thermophilus on rheology of stirred yogurt. Int. J. Food Sci. Technol. 32:213-220.

Rudan, M. A., and D. M. Barbano. 1998a. A dynamic model for melting and browning of Mozzarella cheese during pizza baking. Aust. J. Dairy Technol. 53:95-98.

Rudan, M. A., and D. M. Barbano. 1998b. A model of Mozzarella cheese melting and browning during pizza baking. J. Dairy Sci. 81:2312-2319.

Rehman, S. U., N. Y. Farkye, and B. Yim. 2003. Use of dry milk protein concentrate in pizza cheese manufactured by culture or direct acidification. J. Dairy Sci. 86:3841-3848.

Zisu, B., and N. P. Shah. 2002. Effects of exopolysaccharide producing Streptococcus thermophilus strains on functionality of low fat Mozzarella cheeses. Abstract No. 15B-3 in Proc. Inst. Food Technologists Annual Meeting, Anaheim, CA. Inst. Food Tech., Chicago, IL.

Zisu, B., and N. P. Shah. 2003. Effects of pH, temperature, supplementation with WPC, and adjunct cultures on the production of exopolysaccharides by Streptococcus thermophilus 1275. J. Dairy Sci. 86:3405-3415.

Zisu, B., and N. P. Shah. Textural and functional changes in low fat Mozzarella cheeses in relation to proteolysis and micro-structure as influenced by the use of fat replacers, pre-acidification and EPS starter. Int. Dairy J. (Accepted) 